\title{
ON "Educating Parents": State ANd Family in CANADIAN FOUNDATION FOR CHILDREN, YOUTH AND THE LAWV. CANADA (A.G.)
}

\author{
F.C. DECOSTE*
}

\begin{abstract}
Experience should teach us to be most on our guard to protect liberty when the Government's purposes are beneficent. Men born to freedom are naturally alert to repel invasion of their liberty by evil-minded rulers. The greatest dangers to liberty lurk in insidious encroachment by men of zeal, well-meaning but without understanding.
\end{abstract}

\section{- Justice Brandeis'}

\section{Section 43 of the Criminal Code provides as follows:}

Every school teacher, parent or person standing in the place of a parent is justified in using force by way of correction toward a pupil or child, as the case may be, who is under his care, if the force does not exceed what is reasonable under the circumstances. ${ }^{2}$

In Canadian Foundation for Children, Youth and the Law v. Canada (A.G.), ${ }^{3}$ the Canadian Foundation for Children, Youth and the $\mathrm{Law}^{4}$ — the appellant before the Supreme Court of Canada $^{5}$ - challenged the constitutional propriety of s. 43 on grounds that it violates the rights of children under ss. 7 (security of the person), 12 (cruel and unusual punishment or treatment), and 15(1) (equality) of the Canadian Charter of Rights and Freedoms ${ }^{6}$ and in a fashion as regards each that could not properly be redeemed by $\mathrm{s}$. 1. By a majority of seven

Professor, Faculty of Law, University of Alberta.

Olmstead v. United States, 227 U.S. 438 at 479 (1928) (Brandeis J., dissenting).

R.S.C. 1985 c. C- 46 , s. 43.

(2004), 234 D.L.R. (4th) 257,[2004] S.C.I. No. 6 (QL) [Spanking Case cited to QL, because "spanking" is a cognate of parental office and authority].

Established in 2000, the Foundation is an Ontario non-share capital corporation with charitable status. It is administered by a 15 member Board of Directors, which is elected annually and has a staff of seven (four of whom are lawyers). Its program activities, which operate under the name Justice for Children and Youth, appear to be funded by a variety of foundations (including the Law Foundation of Ontario, the Atkinson Foundation, and the Laidlaw Foundation). Notably, its court challenge of s. 43 at the Ontario Superior and Appeal courts and at the Supreme Court was funded by the Federal Government through the Court Challenges Program. See online: Justice for Children and Youth <www.jfcy.org $>$; Child Rights Information Network <www.crin.org $>$; The Court Challenges Program, Canadian Heritage <www.pch.gc.ca/progs/em-cr/eval/2003/2003_02/4_e.cfm>.

5 Appellant because both the Ontario Superior Court and the Ontario Court of Appeal found against the Foundation and in favour of the Attorney General of Canada (see (2000), 146 C.C.C. (3d) 362 (Ont. Sup. Ct.); (2002), 161 C.C.C. (3d) 178 (Ont. C.A.)). The case proceeded at the Superior Court on the grant of public interest standing to the Foundation. It found its way to the Supreme Court - despite the absence of any factual circumstances - by way of special permission from the Court, because it was the Court's view that it raised a serious legal question that could not be raised in any other reasonable or effective manner. For the latter, see Supreme Court of Canada News Release, "Judgment to be Rendered in Appeal" (9 January 2004), online: Supreme Court of Canada and LexUM $<$ www.lexum.umontreal.ca/csc-scc/en/com/2004/html/04-01-09.2.html $>$.

" Part 1 of the Constitution Act, 1982, being Schedule B to the Canada Act 1982 (U.K.), 1982, c. 11. 
to two, ${ }^{7}$ the Supreme Court upheld the constitutionality of s. 43 against each of the Foundation's three submissions. Indeed, the majority did so in such a fashion as to render unnecessary its consideration of the Foundation's s. 1 submission.

This brief comment will not dally over the constitutional finery in which the majority adorns its argument. Rather, my focus will be on the Court's understanding of the purpose and meaning of s. 43 , since the meat of the judgment unquestionably resides there. More importantly for present purposes, there, too, is disclosed what I take to be its overall character, namely, that it is perverse in its reasoning and pernicious in its result. As regards the latter, my purpose will be to convince that this judgment is but the latest contribution of the judicial branch of the Canadian State to the construction of a legal architecture which, despite the goodwill of its designers, puts under siege not only parental and family autonomy, but civil society and social freedom more generally.

\section{The Court's Construction OF SECTION 43}

The Foundation argued, inter alia, that the vagueness of s. 43 - especially in the phrase "reasonable under the circumstances" - constituted the breach of fundamental justice required by s. 7. Thus did the Appellant's s. 7 submission become occasion for the Court's interpretive enterprise. Section 43, it concluded, "properly construed, is not unduly vague"" and, to make its case the Court undertook, through a hodgepodge of argumentative strategies, ${ }^{10}$ to set straight one and all on the purpose and content of the section.

On the Court's reading, the section's specific purpose is simple enough: "to delineate a sphere of non-criminal conduct within the larger realm of common assault." "Yet, as the Court proceeds, it becomes clear that this purpose is intelligible only in terms of Parliament's intention in having such a purpose. According to the Court, Parliament was seized of a peculiarly pastoral aim and motive in enacting s. 43. That is, its intention was to instruct

Justices Gonthier, Iacobucci, Major, Bastarache and LeBel joined McLachlin C.J's majority judgment with respect to s. 1. Justice Binnie dissented in part (s. 43 violates s. 15(1) but is saved for parents and persons standing in the place of parents, but not for teachers by s. 1). Justices Arbour and Deschamps dissented (Arbour J. found that s. 43 violated s. 7 and that the violation was unjustifiable under s. 1; Deschamps J. found that s. 43 violated s. 15(1) and that the violation was unjustifiable under s. 1). This comment will make only passing reference to the dissenting judgments.

Spanking Case, supra note 3 at para. 14.

Ibid.

11 The Court's construction begins with what, in light of its subsequent inquiries, must be termed ordinary judicial interpretation (ibid. at para. 20: "The words of the statute must be considered in context, in their grammatical and ordinary sense, and with a view to the legislative scheme's purpose and the intention of Parliament"). The Court then seeks "further precision on what is reasonable under the circumstances" (ibid. at para. 31) first from "international treaty obligations" (at para. 31), and next (and, in my view, remarkably, given that the matter at hand concerns criminal liability) from what it terms "social consensus" (at para. 36) and "expert consensus" (at para. 40). Curiously, though it weaves the purpose and content of s. 43 out of this unlikely bolt, when early along, it presents its overall judgment, it fails to mention several of the threads (ibid. at para. 2: "substantial social consensus on what is reasonable correction, supported by comprehensive and consistent expert evidence on what is reasonable in this appeal, gives clear content to s. 43 ").

lbid. at para. 19. 
parents on "the proper and complete conduct of their life business." 12 The Court puts this matter in various ways, ${ }^{13}$ but the core of its message is unmistakable: with s. 43, Parliament adopted "the approach of educating parents against physical discipline."14

The section's content tracks this motive. Consonant with the state's educative instruction, the "solid core of meaning for s. 43 "15 is "minor disciplinary contacts" 16 involving "minimal force of transient or trivial impact." ${ }^{17}$ From this conceptual core, the Court mines a code of disciplinary conduct for parents. ${ }^{18}$ In order properly to conduct their office and to exercise their authority, parents: (i) must not use corrective force against children under two or against children of any age suffering from a disability; (ii) must not use corrective force against children two or older that "causes harm or raises a reasonable prospect of harm," "cruel, inhuman or degrading,", 20 or that involves the use of objects such as a belt or slaps or blows to the head; (iii) must not corporally punish teenagers, though they may use "corrective force to restrain or remove an adolescent from a particular situation, falling short of corporal punishment"; ${ }^{21}$ and (iv) may perform any act of discipline that survives these prohibitions only if they act for "educative or corrective purposes" and in a "sober, reasoned" fashion. ${ }^{22}$ The Court caveats a warning to this code: "where" - in the state's view as announced in this judgment - "reasonable corrective force slips into harmful, degrading, or abusive conduct, the criminal law remains ready to respond.",23

\section{Perverse Reasoning}

There is an obvious and aching criticism of all of this - namely, that because the Court proceeds (ironically, against its own instructions) ${ }^{24}$ in the absence of facts, it condemns itself to pure abstraction and to all the sins to which abstraction in law is an occasion. To be plain about it: because the Court had before it no facts and because, in consequence it was led to

12 This definition of pastoralism comes from Zygmunt Bauman, Legislators and Interpreters (Ithaca, NY: Cornell University Press, 1987) at 20.

13 The Court's approval of the state's pastoral authority over the family fairly abounds in the judgment (see Spanking Case, supra note 3 at paras. 51, 62 and 65).

Ibid. at para. 59.

Ibid. at para. 43

Ibid. at para. 51

Ibid. at para. 59

See especially ibid. at paras. 23-42. Incidentally, teachers are prohibited corporal punishment tout court (ibid. at paras. $38,40,46$ ). Whatever the age of their charges, teachers "may reasonably apply force to remove a child from a classroom or secure compliance with instructions, but not merely as corporal punishment" (ibid. at para. 40). Teachers, like parents, may also use "corrective force to restrain or remove an adolescent from a particular situation, falling short of corporal punishment" (ibid. at para. 46).

Ibid. at para. 30 .

Ibid. at para. 32

Ibid. at para. 46.

Ibid. at para. 24

Ibid. at para. 67

Throughout the decision, the majority stresses the importance of proceeding in matters such as s. 43 on "a case-by-case basis"(ibid. at para. 17). Thus, we are told that what is "reasonable ... depend[s] upon ... factual context" (ibid. at para. 28); that "assessment [of it] must take account of "all the circumstances of the case" (at para. 34); and that "the question must be considered in context and in light of all the circumstances of the case" (at para. 40). In her dissent, Arbour J. rightly and roundly criticizes the fecklessness of the majority's stated commitment to the facts (ibid. at para. 148). 
ground its discourse in the extra-legal ether of "social consensus" ${ }^{25}$ and "expert consensus," 26 the standards it articulates descend not from principle, legal or otherwise, but from unblemished opinion whose authority resides alone in the legislating utterance of them by this Court. But these generalities, as important ${ }^{27}$ and irksome ${ }^{28}$ as they are, are not my purpose. Rather, my intention is to impeach the majority judgment on two more specific grounds, namely, that it is perverse both historically and normatively. I shall discuss each in turn.

The historical argument sounds in the Court's view of the purpose and the intention of s. 43. Recall that the Court's view is that the purpose of s. 43 is "to delineate a sphere of noncriminal conduct within the larger realm of common assault,"29 because, in its view, Parliament's intention in enacting s. 43 was "educating parents against physical discipline." ${ }^{30}$ This understanding defies legal history. Section 43 is not parliamentary innovation. The section, rather, codifies the common law. More importantly, the common law itself was neither innovation nor intervention. It existed, rather, as an acknowledgment, reception, honouring, and enforcement of parental authority and autonomy. ${ }^{31}$ I shall pursue the significance of this acknowledgment shortly. Because it will serve that purpose, it is proper now to outline briefly the origin and contours of parental right.

At common law, parental rights were based in and limited by parental duties to the child. According to Sir William Blackstone, the rights of parents express and make possible the performance of the three duties that parents owe to their children: "their maintenance, their protection, and their education." ${ }^{32}$ These duties bring with them the right to custody and control of children, which itself consists of a bundle of rights, including, inter alia, the right to instruct the child in matters of religion and morality, and the right to discipline the child. It is through this complex of duties and rights that parents perform the responsibility which is uniquely theirs to perform - to nurture the moral and ethical identities of their children.

Ibid. at para. 36 .

Ibid. at para. 40 .

"Important" because they violate, as Arbour J. clearly understood (ibid. at para. 148), the structure and the division of judicial labour under our system of justice and, as she, Binnie and Deschamps JJ. all understood (ibid. respectively at paras. 135-4l, para. 81, and paras. 216-17), the separation of powers that properly structures the burdens and relations between the legislative and judicial branches under our system of governance.

"Irksome" because here our highest Court elected - in violation of the afore-mentioned structure and principle - to join a publically-funded advocacy group in what can only be described as a publicallyfunded seminar-by-invitation on parental authority.

Spanking Case, supra note 3 at para. 19.

Ibid. at para. 59.

Nor should this be a surprise, since the common law, properly conceived, is social in origin and in intention. For a recent statement of this conception, see Nicola Lacey, "Philosophical Foundations of the Common Law': Social not Metaphysical" in Jeremy Horder, ed., Oxford Essays in Jurisprudence. 4th Series (Oxford: Oxford University Press, 2000) 17. And of course, the entire notion of the ancient constitution - to which the Preamble of the Constitution Act, 1867, (U.K.), 30 \& 31 Vict., c. 3 , reprinted in R.S.C. 1985, App. II, No. 5, pledges the Canadian state - arises from just such a view on the relationship between law and social life (see e.g. Jeffrey A. Brauch, ed., Is the Common Law Higher Law? (Littleton, CO: Rothman, 1999); and Ellis Sandoz, ed., The Roots of Liberty: Magna Carta. Ancient Constitution, and the Angol-American Tradition of Rule of Law (Columbia: University of Missouri Press, 1993)).

32 Commentaries on the Laws of England, Volume 1: Of the Rights of Persons, (Chigaco: University of Chicago Press, 1979) c. 16.1.1-2 at 434-41. 
Of course, the rights of parents recognized and honoured at common law were not boundless just because those rights were tied to and limited by the performance of parental duty. This is especially so as regards the right to discipline. The common law recognized the right to discipline as a necessary incident of the obligation to educate. ${ }^{33}$ Yet, while keeping "the child in order and obedience" was necessary to education, parental discipline to achieve "order and obedience" was lawful only if conducted "in a reasonable manner." 34

As will become plain in the next section, my normative criticism of the majority's reasoning is not unrelated to this history. The complaint is simple enough: the Court missed the matter that was properly before it. Indeed - and, in my view, remarkably — only Arbour J. acknowledged the matter at the heart of the Foundation's cause. And no mean matter it is. As put by Arbour J. in her dissent:

[c]orporal punishment is a controversial social issue. Conceptions of what is "reasonable" in terms of the discipline of children, whether physical or otherwise, vary widely, and often engage cultural and religious beliefs as well as political and ethical ones. Such conceptions are intertwined with how other controversial issues are understood, including the relationship between the state and the family. ${ }^{35}$

What was before the Supreme Court of Canada in this matter was the relationship between the state and the family, and through that, the relationship between the state and the institutions, traditions, and practices of social life more generally. That the majority was blind to an issue so obvious, central, and momentous that it confined its commentary on the relationship between law and family life to the utility and consequences of alternative parliamentary policy ${ }^{36}$ is both perplexing and unforgivable. I shall decline here any engagement with the former except to say that, given the pedigree and volume of literature on state and family, ${ }^{37}$ explanation must somehow reside in the influence of the Charter on judicial imagination, especially in regards to the mission, mandate, and processes of the judicial branch. ${ }^{38}$ Joining the second matter, however, is imperative, since it will be my purpose in the next part to identify reasons for the lack of charity I recommend towards the majority's judgment in this case.

\section{Pernicious Resultis}

I claimed earlier that the common law recognized and enforced, rather than constituted, the authority of parents. Because this claim is part and parcel of a larger claim concerning

Ibid. at 440 .

Ibid.

Spanking Case, supra note 3 at para. 185 [emphasis added]

Ibid. at paras. 58, 62, and 68 .

Literacy in this regard would profitably begin with Locke, proceed through Hegel and Arendt, and end with Rawls (see generally Jean Bethke Elshtain, ed., The Family in Political Thought (Amherst: University of Massachusetts Press, 1982)). Of particular interest in the mass of more recent literature are: David William Archard, Children, Family and the State (Aldershot: Ashgate, 2003); and Susan Moller Okin, Justice, Gender and the Family (New York: Basic Books, 1989).

For an attempt to track the nature and effect of this re-imagining, see F.C. DeCoste, "The Halpern Transformation: Same-Sex Marriage, Civil Society, and the Limits of Liberal Law" (2003) 41 Alta. L. Rev. 619; and F.C. DeCoste, "Law Transcendent: Neo-constitutionalism and the Conquest of Ordinary Life" The Newman Rambler [forthcoming in 2004]. 
the relationship that ought properly to exist between the state and family, more precision is in order. Let us then be exact. The object of recognition was first to immunize parental office and practice from the state authority and then to declare when state intervention is proper. So far as the disciplining of children is concerned, the common law deployed the standard of reasonableness. This is a happy settlement, since reasonableness resides first and foremost in the practices of reasonable parents and not in state prescription. So understood, reasonableness was then the stylus used by the common law to draw the line on a case-bycase basis between parental conduct that remained immune, because it was private, and conduct that was open to state correction, because its unreasonableness rendered it public.

The Supreme Court's decision in this case has destroyed the normative sense and structure of this, the standing accommodation between family autonomy and privacy and the protection of children from duty-delinquent - because socially aberrant and unreasonable - parents. In place of a state committed to recognizing, enforcing, and honouring parental office, the Court puts a state whose purpose is the management and direction of parental conduct towards state-articulated ends and means. And in the place of a humble state - so devoted to parental autonomy that it will judge only when specific facts fairly implore it to do so this Court puts forth a state eager to supervise family life overall and by means of reproof issued in advance. This state is a hectoring state and such a state cannot honour, respect, and preserve the autonomy of family life. Just the contrary: in this state, parents become parishioners of a state-constructed church of proper life conduct and they stand in need of the state's pastoral instruction. Nor only that: when their ends and means fail adequately to conform to the state's generic norms for proper parental practice, they deserve its punishment as well.

All of this, in my view, constitutes an assault on parental office and on the good sense and conscience of the men and women who take up the charms, promises, and perils of parenthood. But it is more than even that. If it is admitted that society and not the state is the centre of human life and that family and not, say, friendship or market relations, is the centre of social life, ${ }^{39}$ then to compromise the autonomy of family life, in the way that I believe the Court has here, is to put the whole of social life at risk of state supervision and management. And with this risk comes another: the integrity of our system of law and politics.

Our system of governance proceeds from a single, constitutive truth, namely, that law and politics exist for the sake of persons and of social life, each of which is anterior to and superior to state and law. ${ }^{40}$ From this truth flows the articles of faith on which our way of life entirely depends: (a) that state and law exist to protect the authority and ownership of persons over their fleeting and fragile lives and to conserve and extend social freedom; (b) that state and law are properly predicated on the unity of humankind and are properly devoted to the

Wholesale marxists and radical feminists aside, most would eagerly embrace the family as the womb of social liberty. For a recent judicial admission, see Troxel v. Granville, 530 U.S. 57 at 65 (2000) (where the U.S. Supreme Court describes parental autonomy as "perhaps the oldest of the fundamental liberty interests"). See also Jennifer Roback Morse, "No Families, No Freedom: Human Flourishing in a Free Society" (1999) 16 Soc. Phil. \& Pol. 290; and Nancy F. Cott, Public Vows: A History of Marriage (Cambridge, MA: Harvard University Press, 2000).

4" Finnis has recently delivered this truth with much precision and wisdom (see John Finnis, "The Priority of Persons" in Horder, supra note 31 at 1). 
moral equality and liberty of persons as individuals; and (c) that the state consequently must be a state whose sovereignty over persons and social life is limited by that premise and to that purpose. This faith takes shape institutionally in the familiar architecture of the Rule of Law state; separation of powers and the legal discourse of rights are necessarily the stuff of limited government, because only a state so structured can honour the priority of persons and the primacy of social life. The Supreme Court's reconceptualization of the relationship between state and family and the intrusive claim of sovereignty over family practice to which it led, in my view, compromise the very structure of limited government and, with that, the practice of social freedom.

\section{Building the Post-Liberal State}

I suggested at the beginning that the Court's judgment in this matter is no lapsus. Just the contrary: this judgment must be seen as the latest contribution to the construction of a legal architecture by and through which the institutions, practices, and traditions of private life - what liberals used to call civil society - are being reconceived and installed as public goods properly subject first to state surveillance and then to distribution in accordance with state articulated norms. Unfortunately, this comment cannot examine the jurisprudence that corporately composes this re-engineering of Canadian state and society. What I wish to do instead, by way of a brief conclusion, is to sketch the character of the state that is emerging from it.

This body of judge-made law commits the Canadian state to what I shall moniker "managerialism" and "identitarianism." Al A managerial state is one that aims to manage the life-world of those who are subject to its rule. Its practice is to occupy and to subordinate the institutions, traditions, and practices of civil society, which are made through law to conform to state articulated norms concerning the proper conduct of life. In this fashion, the state recasts its subjects as citizens in the whole of their lives. Citizenship ceases to be a cost necessary for the preservation of social freedom and becomes, rather, a positive good that properly forms and informs persons in all aspects of their state sponsored lives. ${ }^{42}$ The identitarian state constructs, through law, differentiated legal and political subjectivities, which it then accords differential status and, often times, rights. With this, the state arrogates to itself the authority to define, beyond citizenship, who its subjects are; fragments political and legal solidarity; and fractures social and moral fellowship.

It should hardly bear comment that a state of this kind is an illiberal state. Managerialism violates the priority of persons and the primacy of social life; and indentitarianism violates not only those articles of liberal governance, but the premise and practice of moral, legal, and political equality as well. Rather than pursuing that dead horse, I will conclude with a few comments on the fate so far of steering government by these illiberal stars. 
It might be true that bourgeois modernity will, as Marx predicted, ${ }^{43}$ over time melt everything solid - our identities and the bonds and practices of civil society - into air. ${ }^{44}$ What cannot be true is that the Rule of Law state (itself an expression of the modern) should serve as the acid of this corrosion. This is so not just because the state would be abandoning its liberal credentials, but more profoundly because it would then be forfeiting its modern character. Which is to say, the post-liberal state of the character depicted here is an atavistic state - a pre-modern state. Unhappily, under the conditions of social modernity, this state will not have its sovereignty legitimized and its character redeemed by the universal faith of the governors and the governed. Rather, under those conditions, it will be a bullying state, whose experiments in engineering the lives of the governed will work havoc on them, on their identities, and on their practices and commitments. ${ }^{45} \mathrm{I}$ conclude, therefore, that the present experiments of the judicial branch of the Canadian State to disenchant social life through the force of constitutional law works just these evils.

See Karl Marx \& Friedrich Engels, Manifesto of the Communist Party (Moscow: Progress Publishers, $1952)$ at 46: "All that is solid melts into air, all that is holy is profaned."

For explorations of this theme of the modern, see Marshall Berman, All That Is Solid Melts Into Air: The Experience of Modernity (New York: Simon and Schuster, 1982); Louis Dupre, Passage to Modernity (New Haven: Yale University Press, 1993); and Charles Taylor, Sources of the Self: The Making of the Modern Identity (Cambridge, MA: Harvard University Press, 1989).

There is a growing literature on the unhappy results of the state's social engineering of the family (see e.g. Anne Helene Gauthier, The State and Family (Oxford: Clarendon Press, 1996); Carol Smart \& Bren Neale, Family Fragments? (Cambridge: Polity Press, 1999); and Lenore J. Weitzman, The Divorce Revolution (New York: Free Press, 1985). 